\title{
Blepharospasm and periorbital edema after imatinib mesylate: improvement with botulinum toxin
}

\author{
Blefaroespasmo e edema periorbitário após mesilato de imatinibe: melhora com \\ toxina botulínica
}

Hélio A. G. TEIVE'1,2, Francisco M. B. GERMINIANI', Renato P. MUNHOZ², Carlos Henrique F. CAMARGO²

A 71-year-old man on treatment for chronic myeloid leukemia with imatinib mesylate presented with bilateral severe periorbital edema, including his eyelids, later progressing to blepharospasm (Figure A), and was referred to our Botulinum Toxin Outpatient Clinic two years ago. Hematological routine examinations, head and sinuses CT, brain MRI and CSF studies were normal. No treatment for dystonia had been done previously, including botulinum toxin. Botox (70U of onabotulinutoxinA, Allergan Inc., Irvine, CA, USA) was used for treatment of blepharospasm, with partial improvement (Figure B).

Periorbital edema is a fairly common side effect of imatinib mesylate ${ }^{1}$; however, the association with blepharospasm, and the treatment with botulinum toxin, has not been published ${ }^{2}$. When the normal protective blink reflex becomes excessive, the ocular surface may be traumatized. The forceful and excessive eyelid blinking is not only debilitating but also results in further microtrauma to the ocular surface, further exacerbating the disease process. Patients with these conditions can present with chronic pain, photophobia, foreign body sensation, and secondary blepharospasm. Therefore, blepharospasm may be a symptom of ocular surface disease, and the use of botulinum toxin may be beneficial ${ }^{3}$.
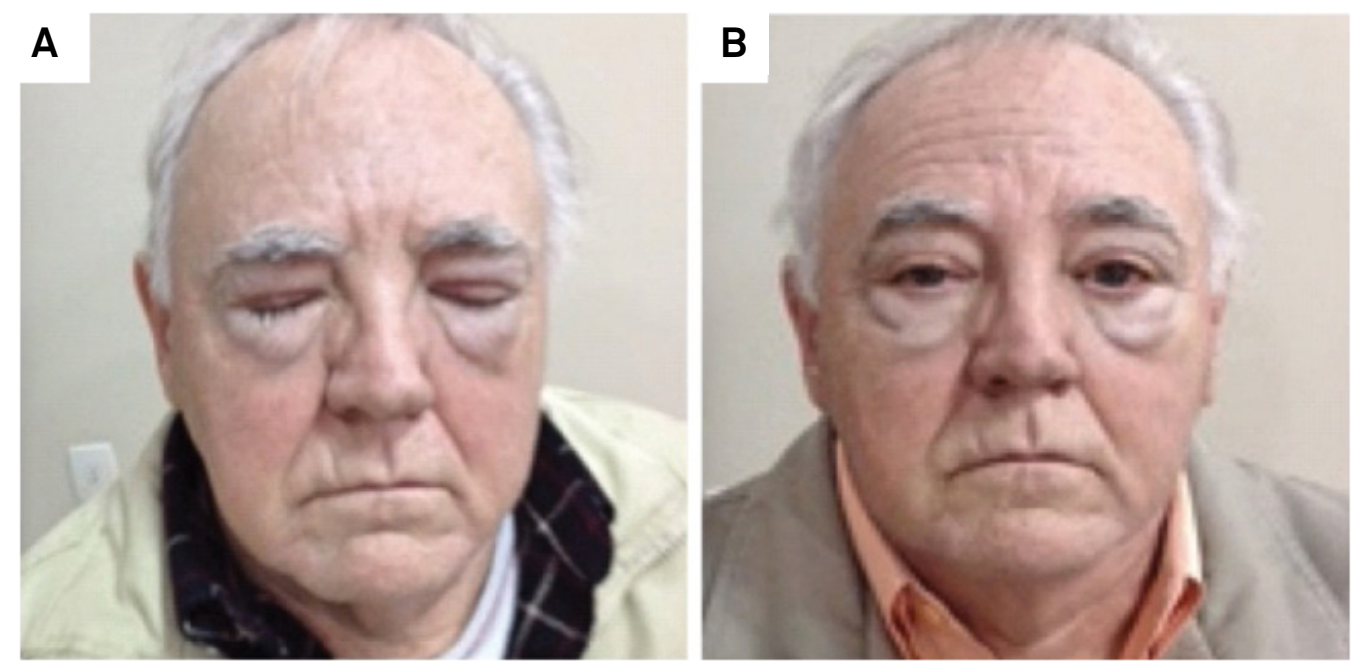

Figure. Patient with severe periorbital edema associated with blepharospasm, secondary to treatment with imatinib mesylate. Imaging before (A) and after (B) botulinum toxin use. (With the patient's permission).

\footnotetext{
${ }^{1}$ Universidade Federal do Paraná, Hospital de Clínicas, Departamento de Clínica Médica, Serviço de Neurologia, Setor de Distúrbios do Movimento, Curitiba PR, Brasil;

${ }^{2}$ Universidade Federal do Paraná, Hospital de Clínicas, Programa de Pós-Graduação em Medicina Interna e Ciências da Saúde, Curitiba PR, Brasil; ${ }^{3}$ University of Toronto, Toronto Western Hospital, Gloria and Morton Shulman Movement Disorders Centre, Toronto,ON, Canada.

Hélio Afonso Ghizoni Teive iD https://orcid.org/0000-0002-4045-1178; Francisco Manoel Branco Germiniani iD https://orcid.org/0000-0001-9494-9759; Renato Puppi Munhoz (iD https://orcid.org/0000-0002-4783-4067; Carlos Henrique Ferreira Camargo iD https://orcid.org/0000-0002-3533-0347 Correspondence: Hélio A. G. Teive; Rua General Carneiro 1103/102 - Centro; 80060-150 Curitiba PR, Brasil; E-mail: hagteive@mps.com.br Conflict of interest: There is no conflict of interest to declare.

Received 05 March 2019; Received in final form 03 May 2019; Accepted 03 May 2019.
} 


\section{References}

1. Esmaeli B, Prieto VG, Butler CE, Kim SK, Ahmadi MA Kantarjian HM,et al. Severe periorbital edema secondary to STI1571 (Gleevec). Cancer. 2002 Aug;95(4):881-7. https://doi.org/10.1002/cncr.10729

2. Simpson DM, Hallet M, Ashman EJ, Comella CL, Green MW, Gronseth G, et al. Practice guideline update summary: Botulinum neurotoxin for the treatment of blepharospasm, cervical dystonia, adult spasticity, and headache: Report of the Guideline Development Subcommittee of the American Academy of Neurology. Neurology. 2016 May; 86(19): 1818-26. https://doi.org/10.1212/WNL.0000000000002560

3. Yen MT. Secondary blepharospasm associated with ocular surface disease. Int Ophthalmol Clin. 2018 Winter; 58(1):71-5. https://doi.org/10.1097/II0.0000000000000205 